\title{
Indicators of the blood clotting system in patients with acantholytic pemphigus
}

\author{
I.O. Oliinyk, A. E-S. E-S. Abdalla, H.K. Kondakova, I.O. Mashtakova \\ SE «Institute of Dermatology and Venereology of NAMS of Ukraine»
}

\begin{abstract}
Research of the level of some indicators of the blood coagulation system in patients with acantholytic pemphigus is extremely important for the prevention of complications. Due to laboratory studies of patients' blood plasma and statistical analysis of the obtained results, the relationship between the severity of dermatosis and changes in the hemostasis system was considered (level of prothrombin index, fibrinogen, partial thromboplastin time, soluble fibrin-monomer complexes, factor XII). Educed reliable dependence that correlates with weight of dermatosis and development of thrombotic complications.
\end{abstract}

Key words: acantholytic pemphigus, hemostasis system, side effects of SGCS therapy, blood clotting system, hemostasis system.

DOI: 10.33743/2308-1066-2021-3-8-11

\section{Introduction}

Acantholytic pemphigus (AP) is an autoimmune disease that affects the mucous membranes and skin. Patients with dermatosis have the appearance of «scalded» skin with blisters on an unchanged background and bleeding erosions [10]. In the early 50's of XX century, in world medical practice, systemic glucocorticosteroids (SGCS) have been widely and successfully used in non-infectious inflammatory diseases [2]. Large progress above autoimmune diseases it was attained due to SGCS.

Nowadays, SGCS remain the means of first-line therapy of AP due to the pronounced anti-inflammatory and immunosuppressive effect, which significantly improves the quality of life of the patient. However, as a result of longterm use of SGCS there are a number of complications that violate the regulatory mechanisms of blood preservation in the bloodstream in the aggregate state. Autoimmune inflammation can initiate thrombosis in intact vessels [14]. Thus, Swedish scientists Zoller B et al. (2012) [15] analyzed the condition of patients admitted to the intensive care unit for the period 1987-2008 regarding ischemic and hemorrhagic stroke, as well as the presence and frequency of autoimmune pathology and found a significant relationship between the two pathologies. The risk of ischemic and hemorrhagic stroke was twice as high in patients in the first year of the disease in 12 nosological units of autoimmune diseases such as rheumatoid arthritis (RA), psoriasis, dermatomyositis, systemic lupus erythematosus (SLE), nonspecific ulcerative colitis (UC). In the United Kingdom, according to a retrospective analysis for the period 19982008 , the risk of venous thromboembolic complications was significantly higher in individuals with autoimmune diseases: autoimmune hemolytic anemia, dermatomyositis, type I diabetes, multiple sclerosis, pemphigus and pemphigoid, Polyarteritis nodosa (PAN), psoriasis, RA, Sjogren's syndrome and SLE [13].
There are many studies of coagulation and fibrinolytic blood systems in patients with autoimmune diseases such as rheumatoid arthritis, autoimmune thyroiditis, nodular periarteritis, Kawasaki disease, dermatomyositis, systemic scleroderma, systemic lupus erythematosus, etc. [7, 11, 12]. There is no information on the state of hemostasis in patients with AP depending on the severity of dermatosis in the literature.

Today, there is a need for a detailed study of the influence of pathogenetic links on the hemostasis system from the immune disorder and the iatrogenic effects of SGCS.

The goal is to carefully monitor the condition of patients with AP during treatment, regular monitoring of clinical, biochemical and coagulation parameters, which will identify risk factors, the occurrence of imbalances in the hemostasis system and prevent the development of their complications.

The objective of the study was to assess the level of certain indicators of the blood coagulation system (prothrombin index, fibrinogen, partial thrombin time, soluble fibrinmonomer complexes, factor XII) in the plasma of patients with AP depending on the severity of dermatosis to prevent and prevent complications.

\section{Materials and methods}

Under the supervision of the Department of Dermatology of the SE «Institute of Dermatology and Venereology of NAMS of Ukraine» were 33 patients with AP for the period 2018-2021. In each case, the diagnosis based on clinical signs and cytological examination. The severity of dermatosis was assessed by the IKEDA index (from 0 to 12 points) [9]. The following parameters were determined: the area of skin lesions, the presence or absence of rashes on the mucous membranes, the severity of Nikolsky's symptom and the number of new blisters occurring per day. Each of the parameters was evaluated on 


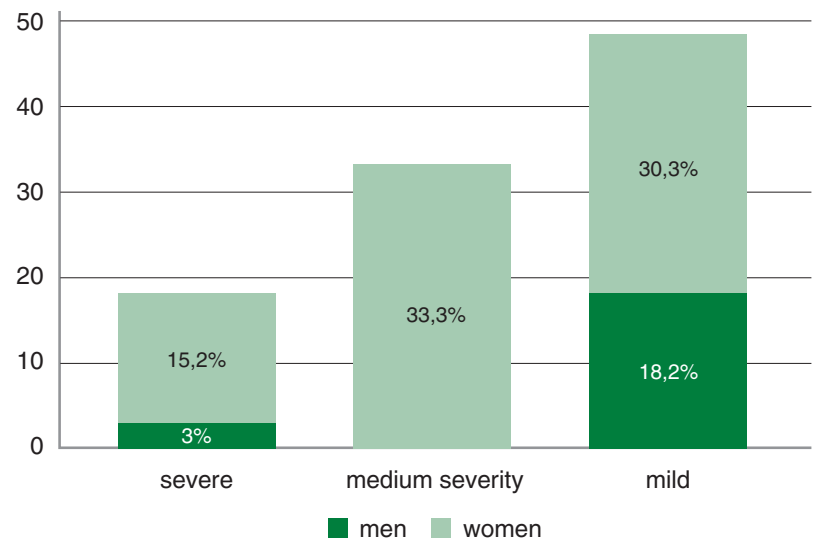

Figure 1. Distribution of patients with AP by severity and sex

a four-point scale from 0 to 3 points. The maximum value of the IKEDA index was 12 points. An estimation was conducted for the amounts of points: $12-8$ points - severe, $7-5$ points - moderate and $<5$ points - mild $[1,9]$.

The age of patients ranged from 29 to 72 years $(52.9$ $\pm 2.0)$. Women were 26 people $(78.8 \%)$, men -7 people (21.2\%). Patients by severity of dermatosis were divided into three groups. Group I included 14 patients whose local condition was assessed as mild, with a mean age of $53.4 \pm$ 2.9 years, dominated by women $(\mathrm{w} / \mathrm{h}-1.3 / 1)$. In group II - 12 female patients with a medium severity of dermatosis whose mean age was $54.5 \pm 3.1$ years and group III patients with severe, widespread process in the number of 7 patients with a mean age of $49.0 \pm 5.3$ years in the ratio of women / men - 6/1 (Fig. 1).

The severity of dermatosis according to the IKEDA index in patients of group I (mild) was on average equal $(3.0 \pm 0.3$ points $)$, in patients of group II (moderate) ( $5.8 \pm 0.2$ points) according to the IKEDA index and patients of group III (severe) $-(9.5 \pm 0.6$ points $)$ at the beginning of therapy.
The level of prothrombin index (PTI), fibrinogen, partial thrombin time (PTT), soluble fibrin-monomer complexes (SFMC), factor XII was determined by standard unified methods [4].

The obtained data were statistically processed using the program Statistica 12.6. We used the average values and errors of the average $(\mathrm{M} \pm \mathrm{m})$. For multiple comparisons between groups, the nonparametric Kruskal-Wallis test and the Mann-Whitney pair test were used to identify significant differences between groups. The differences were considered significant at $\mathrm{p}<0.05$ [6].

\section{Results and discussion}

The results of studies of the main indicators of hemostatic system (HS) blood in patients with AP depending on the severity of the disease are presented in table. 1.

The level of PTI in groups I, II and III of patients with AP was significantly increased compared to that in the control group $\left(\mathrm{p}_{1}<0.05 ; \mathrm{p}_{2}<0.05 ; \mathrm{p}_{3}<0.05\right)$, but had no significant differences between the severity. Thus, the level of PTI in patients of group I (mild) did not differ significantly from the indicators of group II ( $>>0.05)$, but the level of PTI of patients of groups I and II had a statistically significant difference with the indicator of group III $(\mathrm{p}<0.05)$. The study found a significant increase in PTI in individuals with a larger area of skin lesions, that is in severe cases, which indicates increased release of tissue thromboplastin and is characteristic of a violation of tissue integrity (Fig. 2, a).

In patients of group I, the level of plasma fibrinogen had no significant difference with the control group $(\mathrm{p}>0.05)$, and the level of plasma fibrinogen in patients of groups II and III was significantly higher than the level of the control group $\left(\mathrm{p}_{4}<0.05 ; \mathrm{p}_{6}<0.05\right)$. There was no difference in fibrinogen levels between groups I and II $\left(\mathrm{p}_{2}>0.05\right)$ and groups II and III ( $\left.\mathrm{p}_{5}>0.05\right)$, but the level of fibrinogen differed significantly between I and III groups of patients

Table 1. The level of the main indicators of the blood coagulation system of patients with AP depending on the severity of dermatosis $(\mathrm{M} \pm \mathrm{m})$

\begin{tabular}{|c|c|c|c|c|c|}
\hline \multirow[b]{2}{*}{ Indexes } & \multicolumn{3}{|c|}{ Degree of severity } & \multirow[b]{2}{*}{ Control group $\left(n_{0}=20\right)$} & \multirow{2}{*}{$\begin{array}{c}\text { Kruskal-Wallis } \\
\text { test }(H ; p)\end{array}$} \\
\hline & $\begin{array}{c}\text { Mild } \\
\left(n_{1}=14\right)\end{array}$ & $\begin{array}{c}\text { Moderate } \\
\left(n_{2}=12\right)\end{array}$ & $\begin{array}{l}\text { Severe } \\
\left(n_{3}=7\right)\end{array}$ & & \\
\hline PTI (\%) & $\begin{array}{c}101,4 \pm 1,1 \\
\mathrm{p}_{1}<0,05 \\
\mathrm{p}_{2}>0,05 \\
\mathrm{p}_{3}<0,05\end{array}$ & $\begin{array}{l}103 \pm 1,1 \\
P_{4}<0,05 \\
P_{5}<0,05\end{array}$ & $\begin{array}{c}106,2 \pm 1,0 \\
p_{6}<0,05\end{array}$ & $95,92 \pm 1,0$ & $\begin{array}{c}H=30,6 \\
p<0,05\end{array}$ \\
\hline fibrinogen, g/l & $\begin{array}{l}3,3 \pm 0,1 \\
p_{0}>0,05 \\
p_{2}>0,05 \\
p_{3}<0,05\end{array}$ & $\begin{array}{l}3,5 \pm 0,2 \\
p_{4}<0,05 \\
p_{5}>0,05\end{array}$ & $\begin{array}{l}3,8 \pm 0,2 \\
p_{6}<0,05\end{array}$ & $3,1 \pm 0,1$ & $\begin{array}{l}H=12,5 \\
p<0,05\end{array}$ \\
\hline PTT, sec & $\begin{array}{l}26,7 \pm 1,3 \\
p_{1}<0,05 \\
p_{2}>0,05 \\
p_{3}>0,05\end{array}$ & $\begin{array}{c}25,9 \pm 0,8 \\
\mathrm{p}_{4}<0,05 \\
\mathrm{p}_{5}>0,05\end{array}$ & $\begin{array}{l}24,0 \pm 1,0 \\
p_{6}<0,05\end{array}$ & $30,4 \pm 0,5$ & $\begin{array}{l}H=19,7 \\
p<0,05\end{array}$ \\
\hline SFMC, $\times 10^{-2} \mathrm{~g} / \mathrm{l}$ & $\begin{array}{l}3,3 \pm 0,1 \\
p_{1}>0,05 \\
p_{2}>0,05 \\
p_{3}>0,05\end{array}$ & $\begin{array}{l}3,4 \pm 0,2 \\
p_{4}<0,05 \\
p_{5}>0,05\end{array}$ & $\begin{array}{l}3,7 \pm 0,3 \\
p_{6}<0,05\end{array}$ & $3,1 \pm 0,03$ & $\begin{array}{l}H=11,5 \\
p<0,05\end{array}$ \\
\hline factor XII, min. & $\begin{array}{l}6,4 \pm 0,4 \\
p_{1}>0,05 \\
p_{2}>0,05 \\
p_{3}<0,05\end{array}$ & $\begin{array}{l}6,5 \pm 0,4 \\
p_{4}>0,05 \\
p_{5}<0,05\end{array}$ & $\begin{array}{l}10,1 \pm 1,1 \\
p_{6}<0,05\end{array}$ & $6,2 \pm 0,2$ & $\begin{array}{l}H=14,4 \\
p<0,05\end{array}$ \\
\hline
\end{tabular}

Note: $p$ - the level of significance of differences in the averages for pairwise comparison between groups (Mann - Whitney test); $p_{1}-$ differences between group I and control group, $p_{2}$ - differences between groups I and II, $p_{3}$-differences between groups I and III, $p_{4}-$ differences between group II and control group, $p_{5}$-differences between groups II and III, $p_{6}$-differences between III group and control group. 

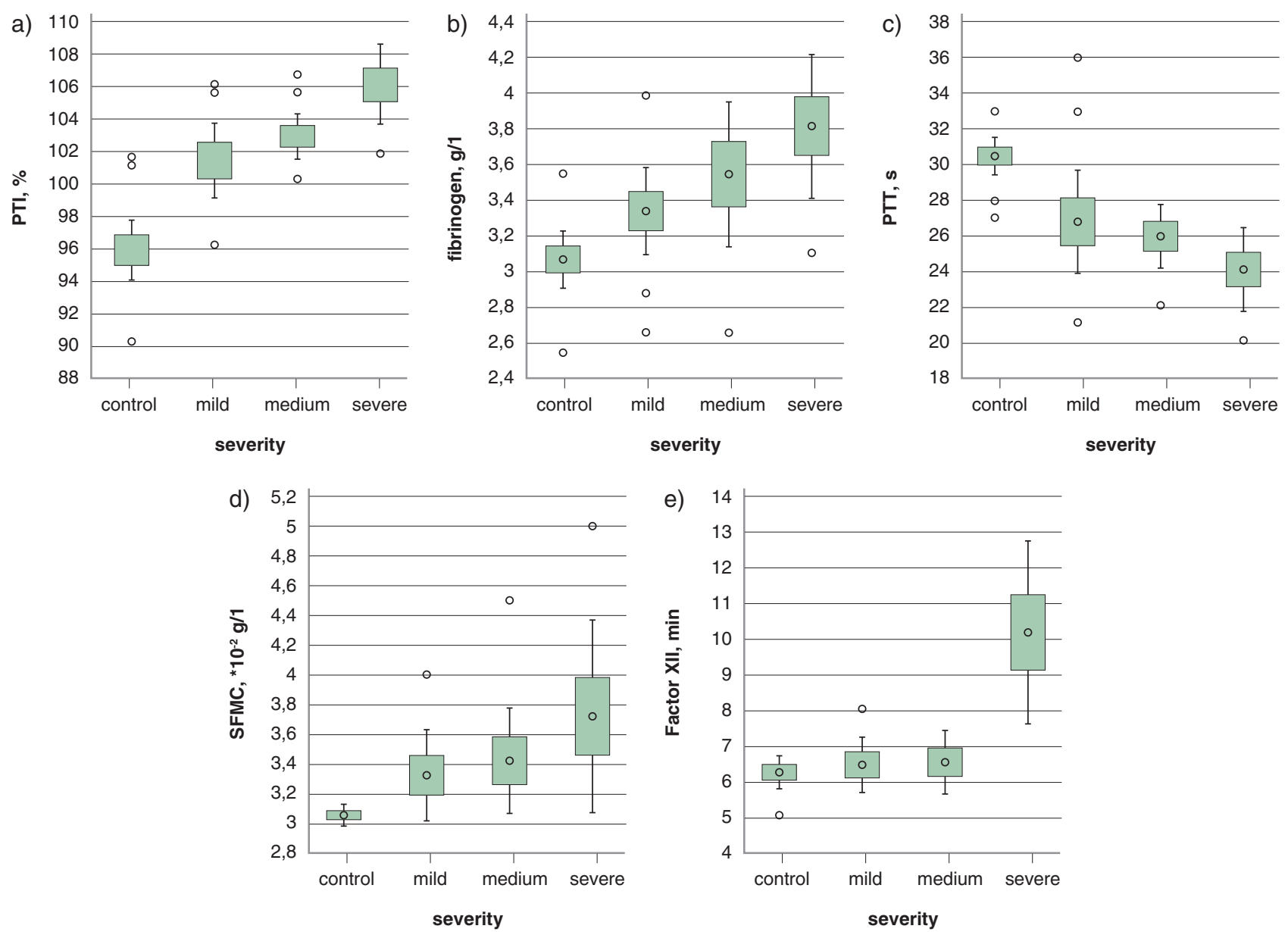

Figure 2. Scope diagrams: a) for PTI; b) fibrinogen; c) PTT; d) SFMC; e) Factor XII

$(\mathrm{p}<0.05)$ : significant growth was found in persons who had a condition characterized by severe and widespread skin process (Fig. 2, b).

The level of PTT in patients with AP was significantly shortened compared with the control group. Thus, in persons of group I it was equal to $(26.7 \pm 1.3)$ sec.; in group II $-(25.9 \pm 0.8)$ sec. and $(24.0 \pm 1.0)$ sec. in patients with AP group III, while the ATT in the control group was equal to $(30.4 \pm 0.5) \mathrm{sec}$. There was a significant reduction in the level of PTT according to the Mann-Whitney test $(\mathrm{p}<0.05)$ in individuals with AP I, II and III groups compared with the control group $\left(\mathrm{p}_{1}<0.05 ; \mathrm{p}_{4}<0.05 ; \mathrm{p}_{6}<0.05\right)$ but there was no significant difference between the severity: I and II groups $\mathrm{p}_{2}>0.05$; II and III groups $\mathrm{p}_{5}>0.05$; I and III groups $\mathrm{p}_{3}>0.05$. As a result of statistical analysis of PTT in patients with AP, a reduction in thromboplastin time was found in patients whose condition was considered severe and had a larger area of skin and mucosal lesions (Fig. 2, c).

SFMC - one of the early markers of thrombinemia is a marker of activation of intravascular coagulation [5]. The increase in the level of SFMC in patients of group I is not statistically significant in comparison with the group of almost healthy individuals $\left(\mathrm{p}_{1}>0.05\right)$, groups I and II $\left(\mathrm{p}_{2}>0.05\right)$, groups I and III $\left(\mathrm{p}_{3}>0.05\right)$, II and III groups $\left(\mathrm{p}_{5}>0.05\right)$. However, there is a tendency to excessive formation of SFMC in persons with a larger area of skin lesions: Group I - $(3.3 \pm 0.1) \times 10^{-2} \mathrm{~g} / \mathrm{l}$; Group II $(3.4 \pm 0.2) \times 10^{-2} \mathrm{~g} / 1$; Group III $-(3.7 \pm 0.3) \times 10^{-2} \mathrm{~g} / \mathrm{l}$. In the control group, the figure was equal to $(3.1 \pm 0.03) \times 10^{-2}$ $\mathrm{g} / \mathrm{l}$. Statistically significant increase in the level of SFMC was observed in patients of group II (moderate) compared with the control group $\left(\mathrm{p}_{4}<0.05\right)$ and group III (severe) with the control group $\left(\mathrm{p}_{6}<0.05\right)$. Therefore, the highest level of SFMC was observed in patients with advanced skin process, who received doses of SGCS from 175 to $80 \mathrm{mg} / \mathrm{d}$ (Fig. 2, d).

Factor XII (Hageman factor) refers to the contact factors of HS. Normally is in the blood plasma in an inactive state. Its activation occurs upon contact with negatively charged surfaces (collagen) in vivo [3,8] which is formed in the presence of soft tissue injuries, burns, etc.

It was found that the indicator of factor XII in patients with mild to moderate AP was slightly increased (6.4 \pm 0.4$)$ minutes. and $(6.5 \pm 0.4)$ min. respectively, while in severe the level of factor XII-a was equal to (10.1 \pm 1.1$)$ minutes, and had a significant reliability of $\mathrm{p}_{5}<0.05$ compared with that in the control group $\left(\mathrm{p}_{6}<0.05\right)$ (Fig. 2, e).

Thus, it was found that in patients with severe AP there is an imbalance in HS: there was a significant increase in the level of PTI, fibrinogen and factor XII-a; shortening of PTT, significantly excessive formation of SFMC.

\section{Conclusions}

Thus, in AP, the mechanisms of hypercoagulation are activated. Determination of individual indicators of the hemostasis system (PTI, fibrinogen, PTT, SFMC and factor XII) in patients with AP, shows that the state of the blood coagulation system depends on the severity of the skin process.

In order to prevent the development of thrombotic complications, HS indicators require careful monitoring and correction of identified disorders. 


\section{Literature}

1. Адаскевич В.П. Диагностические индексы в дерматологии. М.: Изд-во Панфилова; БИНОМ. Лаборатория знаний, 2014. 352 с

2. Гарміш О.О. Глюкокортикоїди при ревматичних захворюваннях: еволюція поглядів. доров'я України. Кардіологія, Ревматологія, Кардіохірургія. 2019. № 3. С. 9-11.

3. Заболотских И.Б., Синьков С.В., Лебединский К.М. Периоперационное ведение пациентов с нарушениями системы гемостаза: клин. рекомендации. М., 2018. 42 с.

4. Камышников В.С. Справочник по клинико-биохимическим исследованиям и лабораорной диагностике. 2-е изд, перераб. и доп.. М.: Медпресс-информ, 2004. 920

5. Принципы клинико-лабораторной диагностики нарушений гемостаза / А.А. Козлов,

А.Л. Берковский, А.Л. Мерлкумян, Т.М. Простакова. М.: Принт, 2014. 44 с.

6. Факторнй, дискриминан, М. Простакова. М.: Принт, 2014.

.Р. Клекка и др., пер. с англ., под ред. И.С. Енюкова. М.. Финансы и статистика, 1989. 215 с. 7. Частота и механизмы нарушений гемостаза при хронической сердечной недостаточности у больных с системными аутоиммунными заболеваниями / О.А. Ефремова, Л.А. Камы

8. Dinulos J.G.H. Habif's Clinical Dermatology. A Color Guide to Diagnosis and Therapy. 7th dition. Elsevier, 2019. 1086

9. Factor XII (Hageman factor) deficiency: a rare harbinger of life threatening complications / Chaudhry, W. El-Sadek, G. Chaudhry et al. The Pan African medical journal. 2019. Vol. 33. P. 39. 10. History of the establishment and revision of diagnostic criteria, severity index and therapeutic guidelines for pemphigus in Japan / S. Ikeda, S. Immamara, I. Hashimoto et al. Arch Dermatol Res. 2003. Vol. 1. P. $12-16$

11. Krishnan V., Araneda M., Hall K. Reactive and clonal thrombocytosis: proinflammatory and hematopoietic cytokines and acute phase proteins. South. Med. J. 2007. Vol. 144. P. 417-420. 12. Onat A., Direskeneli $H$. Excess cardiovascular risk in inflammatory rheumatic diseases: 13 13. Risk of subsequent ischemic and hemorrhagic stroke in patients hospitalized for immunemediated diseases: a nationwide follow-up study from

14. Risk of venous thromboembolism in people admitted to hospital with selected immune14. Risk of venous thromboembolism in people admitted to hospital with selected immuneBMC Med. 2011. Vol. 10, Iss. 9. 8 p. doi: 10.1186/1741-7015-9-1.

15. Westerweel P.E., Verhaar M. C. Endothelial progenitor cell dysfunction in rheumatic di-
. sease. Nat Rev Rheumatol. 2009. Vol. 5, Iss. 6. P. 332-340.

\section{References}

1. Adaskevich VP. Diagnosticheskie indeksyi v dermatologii [Diagnostic indices in dermatology]. M.: Izd-vo Panfilova; BINOM. Laboratoriya znaniy; 2014. 352 p. [In Rus.]

2. Harmish $\mathrm{OO}$. Hliukokortykoidy pry revmatychnykh zakhvoriuvanniakh: evoliutsiia pohliadiv Glucocorticoids in rheumatic diseases: the evolution of views]. Zdorovia Ukrainy. Kardiolohiia, [

3. Zabolotskih IB, Sinkov SV, Lebedinskiy KM. Perioperatsionnoe vedenie patsientov s nausheniyami sistemyi gemostaza: klin. rekomendatsii [Perioperative management of patients with 4. Ka the hem

4. Kam tornoi dyahnostyke [Handbook of clinical and blochemical research and labolatory diagnostics.

5. Kozlov AA, Berkovsky AL, Merlkumyan AL, Printal ova TM. Printsipyi kliniko-laboratorno

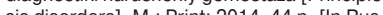
6. Kim

Oldenderfer MS, Bleshfild RK. Faktornyiy, diskriminantnyiy i klasternyiy analiz [Factorial, discriminant and cluster analysis]; per. s angl.; pod red. I.S. Enyukova. M.: Finansyi i statistika; 1989. 215 p. [In Rus.]

7. Efremova OA, Kamyishnikova LA, Ilchenko AS, Fetisova VI. Chastota i mehanizmyi narusheniy gemostaza pri hronicheskoy serdechnoy nedostatochnosti u bolnyih s sistemnyimi autoiming failure in patients with systemic autoimmune diseases]. Nauchnyie vedomosti Belgorodskogo gosudarstvennogo universiteta. 2016;19(240),35:48-53. [In Rus.]

8. Dinulos JGH. Habif's Clinical Dermatology. A Color Guide to Diagnosis and Therapy. 7th Edition. Elsevier; 2019. 1086 p.

9. Chaudhry L, El-Sadek W, Chaudhry G, Al-Atawi FE. Factor XII (Hageman factor) deficiency: (a) 10. Ikeda S, Immamara S, Hashimoto I, Morioka S, Sakuma M, Ogawa H. History of the 10. Imeda S, Imamaris phigus in Japan. Arch Dermatol Res. 2003;1:12-16.

11. Krishnan V, Araneda M, Hall K. Reactive and clonal thrombocytosis: proinflammator 11. Krishnan V, Araneda M, Hall K. Reactive and clonal thrombocytosis: proinflammat

12. Onat A, Direskeneli $H$. Excess cardiovascular risk in inflammatory rheumatic diseases:

pathophysiology and targeted therapy. Curr Pharm Des. 2012;18(11):1465-1477.

13. Zoller B, Li X, Sundquist J, Sundquist K. Risk of subsequent ischemic and hemorrhagic stroke in patients hospitalized for immune-mediated diseases: a nationwide follow-up study from Sweden. BMC Neurol. 2012;18(12):41.

14. Ramagopalan SV, Wotton CJ, Handel AE, Yeates D, Goldacre MJ. Risk of venous throm14. Ramagopalan SV, Wotton $C J$, Handel AE, Yeates $D$, Goldacre MJ. Risk of venous thromlinkage study. BMC Med. 2011;10(9):8. doi: 10.1186/1741-7015-9-1.

15. Westerweel PE, Verhaar MC. Endothelial progenitor cell dysfunction in rheumatic disease. Nat Rev Rheumatol. 2009;5(6):332-340.

\section{ПОКАЗНИКИ ЗГОРТАЛЬНОЇ СИСТЕМИ КРОВІ У ХВОРИХ НА АКАНТОЛІТИЧНИЙ ПЕМФІГУС}

\section{I.O. Олійник, А.E-C.E-C. Абдалла, А.К. Кондакова, І.О. Маштакова}

ДУ «Інститут дерматології та венерології НАМН України»

\section{Резюме}

Дослідження рівня деяких показників згортальної системи крові у хворих на акантолітичний пемфігус є вкрай важливим задля запобігання ускладненням. Завдяки лабораторним дослідженням плазми крові пацієнтів і статистичного аналізу отриманих результатів було розглянуто взаємозв'язок ступеня тяжкості дерматозу і змін показників системи гемостазу (протромбінового індексу, фібриногену плазми, активованого часткового тромбінового часу, розчинних фібрин-мономерних комплексів і ХІІ-а фактора). Виявлена достовірна залежність між тяжкістю дерматозу і розвитком тромботичних ускладнень.

ключові слова: акантолітичний пемфігус, система гемостазу, побічні явища СгКС-терапії, згортальна система крові.

\section{ПОКАЗАТЕЛИ СВЕРТЫВАЮЩЕЙ СИСТЕМЫ КРОВИ У БОЛЬНЫХ АКАНТОЛИТИЧЕСКИМ ПЕМФИГУСОМ}

\section{И.А. Олейник, А. Э-С.Э-С. Абдалла, А.К. Кондакова, И.А. Маштакова}

ГУ «Институт дерматологии и венерологии НАМН Украины»

\section{Резюме}

Исследование уровня некоторых показателей свертывающей системы крови у больных акантолитическим пемфигусом крайне важно для предупреждения осложнений. Благодаря лабораторным исследованиям плазмы крови пациентов и статистического анализа полученных результатов была рассмотрена взаимосвязь степени тяжести дерматоза и изменений показателей системы гемостаза (протромбинового индекса, фибриногена плазмы, активированного частичного тромбинового времени, растворимых фибрин-мономерных комплексов и XII-а фактора). Выявлена достоверная зависимость между тяжестью дерматоза и развитием тромботических осложнений.

Ключевые слова: акантолитический пемфигус, система гемостаза, побочные эффекты СГКС-терапии, свертывающая система крови, система гемостаза.

\section{Відомості про авторів:}

Олійник Ірина Олександрівна - д-р мед. наук, ст. наук. співроб., головний наук. співроб. відділу дерматології, інфекційних та паразитарних захворювань шкіри ДУ «Інститут дерматології та венерології HАМН України». E-mail: otdderm@ukr.net

ORCID ID: $h$ ttp://orcid.org/0000-0002-6408-830X

Абдалла Алія Ель-Саед Ель-Седик - аспірант відділу дерматології, інфекційних та паразитарних захворювань шкіри ДУ «Інститут дерматології та венерології НАМН України». E-mail: aliya.abdalla04@gmail.com

ORCID ID: https://orcid.org/0000-0002-6180-549X

Кондакова Ганна Костянтинівна - канд. біол. наук, завідуюча лабораторією біохімії ДУ «Інститут дерматології та венерології НАМН України». E-mail: idvnamnu@ukr.net

ORCID ID: https://orcid.org/0000-0002-7739-1922

Маштакова Ірина Олексіївна - канд. мед. наук, ст. наук. співроб., ст. наук. співроб. відділу дерматології, інфекційних та паразитарних захворювань шкіри ДУ «Інститут дерматології та венерології HАМн України». E-mail: otdderm@ukr.net ORCID ID: https://orcid.org/0000-0002-3592-6896 